\title{
ESSENTIALS IN FACTORY INSPECTION
}

\author{
By Hon. John H. Morgan, \\ Chief Inspector of Workshops and Factories, Ohio.
}

Factory inspection and factory laws generally, if not invariably, include the child labor laws. In fact, I know of no state having a bureau organized for the express purpose of enforcing child labor legislation.

In successful factory inspection there are at least three essentials : laws, means of enforcement, and the moral support of the people. The laws should be reasonable, definite, practical, and of as high a standard as can be rigidly enforced without antagonizing public sentiment. The laws of several states composing a group geographically or industrially should be uniform; in fact, we should have uniform laws throughout the nation, not only that they may be enforced more easily, but in justice to the manufacturers carrying on the same class of industries. I would not be understood, however, as favoring a lowering of the standard of the laws of any state in order to secure this much-desired uniformity. That is not my idea of successful factory legislation. For instance, in the Ohio Valley states Illinois is the only one having an eight-hour work-day for minors under the age of sixteen years, and this law is enforced successfully. We have not tried to induce Illinois to increase the number of work hours, but have followed her example. Ohio has enacted during this session of the legislature a similar law, which will go into effect on the first day of July, this year. In fact, it is a little in advance of the Illinois law, in that it provides that no girl under the age of eighteen shall be employed more than eight hours a day or forty-eight hours a week. We hope the rest of this. group of states will soon enact similar legis!ation.

I will not attempt to go into the defects of the laws of any state in particular. We who work in this field know the imperfections only too well. Even in the best of factory laws there is much room for improvement.

Factory inspection is a practical question, which must be (IOI) 
settled by experience. It need not be, however, by experience born of selfishness, and greed, and indifference. We are appalled by some public calamity, such as an Iroquois Theater fire, the burning of the Slocum, or the sacrifice of 175 children as in the fire in the Collinwood school building. These horrify and terrify us, and cause us to smart with indignation; and rightly so, generally, because these catastrophes can usually be traced to the mad rush for wealth, or a penurious false economy in construction of public buildings, or wilful negligence and indifference. But, if we would only realize it, these public calamities are a small factor compared with the vast slaughter that is going on, day in and day out among the employees in the shops, factories and mines, and on our railroads. The sorry part of it is a large part of it could be avoided by the strict enforcement of adequate laws.

In the wake of the prosperity we have of recent years been experiencing has come bane as well as blessing. Industry and prosperity have come to us by leaps and bounds; we have come to be the workshop of the world. It has been one continuous march of progress from the time the master and workman were one and the same, working to supply the needs of himself and his neighbors, on through the various stages of the small shop and factory employing a few helpers to the large establishment employing hundreds, and finally to a concentration of industries whereby thousands and thousands of employees are under the control of a corporation or trust.

\section{Public Awakening}

I have said it was one continuous march of progress, but is this true in the highest sense? Is it not possible that as a nation we have had our vision so centered on material things that we have forgotten, or are forgetting, the better things of life? Employer and employee have been so busy making money that they have had little time, and less inclination in too many instances, to give any thought to the real welfare of mankind. Neither is without fault in this connection, for I have seen as much greed manifested among workmen as among employers. Human nature seems to be about the same in all walks of life, when given full swing. The piecework system and the sub-contract have developed to such an extent that we are grinding out the very lives of our 
working people. Human life is the cheapest grist that passes through our wheels of industry. These conditions have grown on us so gradually and stealthily that we have scarcely realized the enormity of the crime. In fact, we have rather accepted it as the legitimate condition of the work-a-day world.

I have referred to the sad catastrophe at Collinwood, where one hundred and seventy-five children lost their lives in a burning school building. The whole nation paused to sorrow, pity and blame. The sacrifice at one time, in such tragic manner, of so many, was what appalled us. But the sacrifice that is made little by little each day by the working children of this country, is passed almost wholly unnoticed by a majority of the people. And it is a sacrifice, for we should have legislation throughout the entire country, and the means to enforce it, that would prevent this jeopardy of morals, health, and life itself. It seems frightful to think that a people as intelligent as the Americans, cannot, or will not, read the writing on the wall, until some great public sacrifice of life is made. In cases like the Collinwood disaster, the awakening is instantaneous, and preventive measurcs are quickly put into effect. But it has taken us years to slowly awaken to the insidious havoc wrought in the lives of our working people by our long neglect of factory conditions, especially as they apply to young people. Recently the crusaders against the White Plague have realized how many victims are enrolled from the ranks of factory employees, and they have joined the ranks of kindred organizations in helping all they can to better the conditions.

The future of our country is not very promising unless we fully realize at an early date the responsibility resting upon us in these matters. What we need in this country is a great awakening to the value of human life, of health and of morals. We need to fix the responsibility.

One of the chief elements of success in any law is the enforcement thereof. We have learned that simply placing laws on the statute hooks does not remedy the evils; it is the enforcement that brings relief.

\section{More Inspectors Needed}

Very few if any of the states with regularly organized factory inspection departments have as many inspectors as are needed 
to perform the work in the manner required. One of the longstanding needs in Ohio, is a material increase in the number of inspectors. We have succeeded during this session of the General Assembly in passing a bill amending the present child labor laws and providing for the appointment of eight women factory inspectors, or visitors, whose duties shall pertain to establishments in which women and young people are employed. This law, as I have previously stated, goes into effect the first day of next July. We shall then have a child labor law in force which we hope will be accepted as a standard by every state not so far advanced in such legislation, and we believe we will have the means of securing its practical enforcement. We are hopeful, however, that the present legislature will give us an increase in the number of factory and building inspectors, in order that this branch of the work, for which the department was specifically organized, may have proper consideration.

\section{Difficulties of Inspection}

The creed of the factory inspector is, or should be, Protection : protection of the life, health and morals of the workers, old and young, male and female. In this work the factory inspector occupies a peculiar position. He stands as the representative of the people, protecting the only capital the worker has-his health and morals. Therefore, to look for defects is the lot of the alert inspector. No matter how well equipped, nor how well regulated a factory or establishment may be, it is still his duty to guard against the unexpected as far as possible. To be sucessful he must be a practical mechanic of good habits; diplomatic in his relations with men; strong enough to demand and insist that the law be complied with, and in full sympathy with all features of the work, including the child labor laws. He should have sufficient force of character to rise above the pessimistic character of his work, or he will be lost ; he should be a real optimist at heart. My idea of successful factory inspection is to secure by frequent visits the co-operation of employers in maintaining fair conditions.

For years we have had in Ohio, a very good child labor law, as well as very fair general factory laws, and some effort has been made to enforce them, but I will frankly say we are a long way from Utopia. In my opinion, human nature is about the same on both 
sides of the Ohio River, and I believe it is no different there from that in other localities. I, therefore, am at a loss to comprehend the statements of inspectors who claim that employers do not misrepresent conditions; that they have never had employers make false statements about their minor employees, and that they have the hearty co-operation of the employers of their states. We have many broad-minded, philanthropic employers in the State of Ohio-men with whom it is a pleasure for the factory inspector to do business ; but we could not truthfully state that the employers all over the state give us their hearty support. In fact, we have had to fight every inch of the way, and are still fighting. We have fought for legislation, and we have contended for enforcement. Our inspectors have gone into establishments expecting to find ideal conditions as far as child labor was concerned, only to learn that the few minutes' wait at the office was sufficient to allow the children to be sent out the back way. In conducting our squad campaigns, we have had instances of a number of inspectors entering a department store a few minutes ahead of the regular inspector for the district, who is generally well known; and on the arrival of the latter, the mad rush of the floor managers to get the children out while the inspector was detained in the office, resembled a panic. When this was done they found the store full of inspectors and themselves caught in the act of trying to deceive.

The age and schooling certificates are also a source of more or less trouble to the inspector. For while we have the able, cheerful and conscientious support of some of the school authorities in this feature of our work, there are too many who cannot see their way clear to take it up in the right spirit, and this makes it difficult for both employer and inspector.

These are only slight reminders of some of the obstacles the inspector meets in his work. His position is not an enviable one. $\mathrm{He}$ is frequently a public target for criticism. People interested in the children want to know what the inspector is doing that so many children are allowed to work in the factories. The adult worker cannot understand why his grievances are not righted, and there is a clamor from the general public for protection in places where they assemble for learning or amusement. At present the public buildings are receiving the attention of the entire Ohio department, but 
this is not always accepted gracefully as a reason for failure to keep up the factory and child labor part of our work at the same time.

\section{Public Responsibility}

But, with all this, I am hopeful that we are about to see the dawn of better conditions in every respect. Public sentiment is becoming enthused, not spasmodically, but with a steady, growing, enduring enthusiasm, and it is this which will leaven the larger part of this whole question. It is the greatest essential, in my estimation. Public sentiment is what demands laws for the good of the people, and it is public sentiment that enforces them. It was public sentiment aroused, developed and stimulated by the labor organizations, and the women's welfare and patriotic organizations, that secured the passage of the eight-hour law for minors in Ohio; and it will be this same influence that will make possible a rigid enforcement of it.

The National Child Labor Committee, representing public sentiment, as it does, in a sort of semi-official manner, is a very important factor in the solution of the great industrial problems. It represents in large measure the crystallized sentiment in this work, and it is meet that we should come together in this way to learn of each other's experiences, difficulties, purposes, and principles, to the end that we may work together harmoniously and understandingly.

The labor organizations of the country have for years recognized the evils in the industrial world, and have fought valiantly against their progress. They have endeavored to put into practice and to teach the principles of the brotherhood of man. They have tried to scatter the seeds of altruism, brotherliness, and fair-play far and wide, and I feel that some of their efforts have fallen on good ground, and in due season we shall reap the harvest. Nay, if I read the signs of the times aright, the harvest is ripening, and the reapers are gathering in great numbers. Broad-minded men and women in all ranks of life are devoting time and energy to this vital work. People of leisure and wealth; people of learning and wide experience; college students, club women, labor and patriotic and political organizations, the church and the press, have all taken hold of this work in dead earnest, and its success is assured. We fully realize that factory legislation is really only in its infancy; that its possibilities are great, and while our progress may be slow at times, it will never stop altogether. There is always a goal to be 
attained, and each and every one may have his share in the result, if he will.

"There's a fount about to stream, There's a warmth about to glow,

There's a flower about to blow,

There's a midnight blackness changing into gray;

Men of thought and men of action,

Clear the way." 